\title{
JOURNAL.RU
}

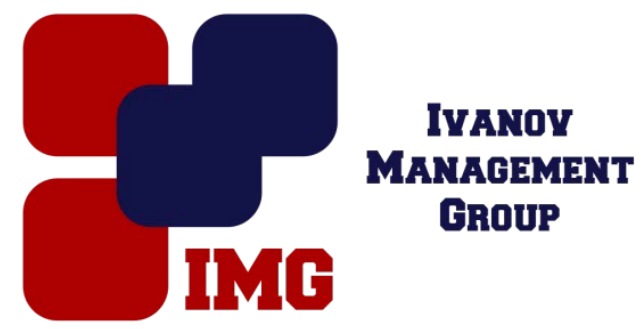

Филатова И.Ю.

ПАО «Роствертол», МСЧ Ростов-на-Дону, Россия

doi: 10.18411/lj-30-11-2016-2-12

idsp 000001:lj-30-11-2016-2-12

\section{Носовые кровотечения у больных с атрофическим ринитом}

Носовое кровотечение (НК) может быть симптомом различных заболеваний локального и системного характера [1, 2]. Около 4\% населения страдает так называемыми привычными носовыми кровотечениями [3], которые повторяются несколько раз в год на протяжении длительного времени. Причинами таких кровотечений, как правило, являются локальные заболевания полости носа: атрофический ринит (АР), перфорация перегородки носа, сосудистые опухоли, варикозное расширение сосудов слизистой оболочки носа $[3,4]$. Возможно возникновение привычных НК и при общих заболеваниях, в частности, при геморрагических диатезах, на фоне длительного приема антикоагулянтов $[5,6,7]$.

В последние годы значительно чаще, чем раньше во время амбулаторных приемов стали выявляться субатрофические и атрофические процессы в полости носа.

Целью нашего исследования было изучение роли атрофического ринита в возникновении рецидивирующих НК у работников вредных производств.

Материал и методы исследования. Мы исследовали 19 рабочих горячего цеха в возрасте от 38 до 52 лет, страдающих привычными НК. Из числа исследованных были исключены больные, перенесшие хирургические вмешательства в полости носа, страдающие сахарным диабетом и другими эндокринными заболеваниями.

Помимо традиционного общеклинического исследования, больным производили коагулограмму, определение адгезивно-агрегационных свойств тромбоцитов и длительности кровотечения по Дуке. Состояние слизистой оболочки носа оценивали по данным эндоскопии и скорости мукоцилиарного транспорта (МЦТ). Последнюю определяли с помощью сахаринового теста, контрольную группу для этого исследования составили здоровых10 мужчин в возрасте от 30 до 46 лет, не имеющих жалоб на патологию ЛОР органов. 
Результаты исследования.

Из анамнеза установлено, что НК у исследуемых больных повторялись с частотой 4 и более раз в год на протяжении последних 2-3 лет, возникали как в состояния покоя, так и при различных нагрузках (перегревание, высмаркивание носа, наклоны туловища вперед). Периоды учащения кровотечений чередовались с ремиссиями, причин которых больные указать не могли. Основным источником НК была передняя треть перегородки носа (зона Литтля). Других проявлений кровоточивости (спонтанных и спровоцированных кровоизлияний в кожу и подкожную клетчатку, суставы, склеры, сетчатку, десневых, маточных кровотечений, кровоточивости при травмах) не отмечено. Ранее все больные были обследованы в гематологических стационарах, нарушений коагуляционного и тромбоцитарного гемостаза не обнаружено. Повышений артериального давления зарегистрировано не было.

При исследовании общего анализа и коагуляционных свойств крови больных с НК отклонений от нормы не отмечалось. Лабораторные методы исследования тромбоцитарного компонента гемостаза (длительность кровотечения по Дуке, исследование агрегации и адгезии тромбоцитов) не выявили наличия тромбоцитопатии.

При осмотре больных с рецидивирующими НК патологические изменения слизистой оболочки носа $(\mathrm{COH})$ были обнаружены у 16 из 19 человек: у 13 отмечена сухость $\mathrm{COH}$ в передних отделах перегородки носа с образованием корок, у 3 больных - наличие расширенных, извитых сосудов в передней трети перегородки носа. У остальных 3 больных видимых изменений $\mathrm{COH}$ не отмечено.

При проведении сахаринового теста у всех больных с НК было выявлено замедление мукоцилиарного транспорта по сравнению с контрольной группой: время МЦТ у здоровых лиц составило в среднем $13,4 \pm 2,38$ минут, а у больных с НК $-22,5 \pm 3,15$ минуты ( $<0,05)$, причем более выраженное увеличение времени МЦТ зарегистрировано у больных с наличием клинических признаков атрофических изменений в полости носа. Замедление скорости МЦТ у больных с АР было отмечено и в других исследованиях.

Таким образом, у большинства исследованных нами больных традиционные клинические методы исследования (общий анализ крови, коагулограмма) не выявили отклонений от нормы. Однако у 16 из 19 больных (в $68 \%$ случаев) были обнаружены признаки АР в виде сухости слизистой оболочки, образования корок. У всех больных наблюдалось значительное замедление мукоцилиарного транспорта, коррелирующее со степенью выраженности атрофических изменений в полости носа.

Этиология вторичного атрофического ринита до конца не изучена. Установлено, что АР может быть результатом длительного воздействия вредных профессиональных факторов на слизистую оболочку носа [8]. В числе других возможных предрасполагающих факторов называют неблагоприятное влияние факторов окружающей среды: антропогенного загрязнения и повышенной 
солнечной радиации [9]. Эти неблагоприятные факторы вызывают также развитие вторичного иммунодефицита $[10,11]$. G.J. Garcia et al. [12] предполагают, что ключевую роль в патофизиологии атрофического ринита играет избыточное испарение жидкости с поверхности слизистой оболочки. Учитывая эти обстоятельства, климатические условия нашего региона в сочетании с профессиональными вредностями могут играть решающую роль в развитии атрофических процессов в слизистых оболочках верхних дыхательных путей. 


\section{Литература}

1. Волков А.Г., Бойко Н.В., Быкова В.В., Жданов В.Г. Совершенствование способов остановки носового кровотечения. Вестник оториноларингологии. 2010. № 4. С. 9-12.

2. Бойко Н.В., Колмакова Т.С. Исследование биогенных аминов у больных с носовыми кровотечениями на фоне вегетативной дисфункции. Folia Otorhinolar. et Pathol Res. 2015. T 2. № 21. C. 27-29.

3. Beran M., Petruson B. Changes in the nasal mucosa of habitual nose-bleeders // Acta Otolaringol (Stockh).-1986. Vol. 102. P. 308-314.

4. Бойко Н.В. Хирургическое лечение рецидивирующих носовых кровотечений. Рос. ринология. 1999. № 2. 29.

5. Бойко Н.В., Шатохин Ю.В., Быкова В.В. Патогенетическое лечение рецидивирующих носовых кровотечений на фоне гипертонической болезни. Российская ринология. 2007. № 2. С. 58.

6. Бойко Н.В. Носовые кровотечения как осложнение антитромботической терапии // Российская ринология. 2011. Т. 19. № 4. С. 29-32.

7. Бойко Н.В., Шатохин Ю.В. Патогенез носовых кровотечений у больных с артериальной гипертензией. Вестник оторинолар. 2015. Т. 80. № 5. С. 4145.

8. Агапитова М.Е., Кофанов Р.В., Куренков Е.Л. Оптимизация диагностического алгоритма при хроническом рините у работников, подвергающихся воздействию пыли металлургического производства // Российская оториноларингология - Приложение. 2007. С. 248-251.

9. Колмакова Т.С., Тупиков В.А., Шпак Л.И. Влияние антропогенного загрязнения на здоровье жителей Ростовской области. Медицинский вестник Юга России. 2012. № 3. С. 16-18.

10. Стагниева И.В., Гукасян Е.Л., Сагакянц А.Б. Нарушение нейроиммунной реактивности у больных риносинуситом // Российская ринология. 2015. Т. 23. № 1. C. 25-28.

11. Стагниева И.В., Симбирцев А.С. Иммуномодулирующая терапия у больных риносинуситом с латентным течением // Медицинская иммунология. 2015. Т. 17. № S. С. 423.

12. Garcia G.J., Bailie N., Martins D.A. Atrophic rhinitis: a CFD study of air conditioning in the nasal cavity // J. Appl. Physiol. 2007. Vol. 103, №3. P.1082-1092. 